\title{
Humorous political stunts: Speaking "truth" to power?
}

\author{
Majken Jul Sørensen \\ Faculty of Arts, University of Wollongong
}

\begin{abstract}
The article introduces the concept of humorous political stunt and a new model of five types of stunts that in distinct ways challenge the prevailing order and transcend established power relations. The five types, named supportive, corrective, naive, absurd and provocative, each relate to those in power and their rationality in a different way. Supportive stunts are framed as ostensible attempts to help and protect from harm, here exemplified with a search for landmines in a Belgian bank investing in dubious companies. Corrective stunts present an alternative version of the power holders' truth, illustrated with a Swedish peace organisation's parody webpage of a government agency established to support arms export. In an example of a naive stunt, Burmese opposition challenges the military junta from behind a pretended innocence. Polish resistance to socialist rule shows how the absurd stunt defies all rationality. In a contemporary Russian provocative stunt directed towards the secret police, the pranksters transcend power by appearing not to care about the consequences of infuriating the powerful. In all instances, humour is the tool of serious dissent and protest attempting to humiliate and undermine the powerful. The model has been applied to more than 40 stunts and illustrates methods of speaking truth to power that exploit humorous techniques such as irony, exaggeration or impersonation. The examples also document that humour is not always carried out at the expense of those at the bottom of society, but can indeed kick upwards in order to aim for change of the status quo.
\end{abstract}

Keywords: humorous political stunts; grassroots organisations, political activism.

\section{Introduction}

Humour is special way of communicating. In itself, it is neither good nor bad. It can be used to hurt other people, and it can be used to make them happy, just like other methods or mediums for communication. Meyer (2000: 323) calls this ability to both unite and divide "the paradox of humour". My focus is on political humour that aims to criticise those in 
power. The examples I provide are from grassroots organisations that "kick upwards" and criticise abuse, self-righteousness and dominant truths and world views.

Four aspects are essential for identifying the phenomenon of humorous political stunts. A stunt is a type of performance or action which is carried out in public and in one way or another confronts the perspective of those who represent a dominant discourse. This can be a major and all-pervading discourse such as militarism, consumerism and neo-liberalism, or it can be a more limited political discourse controlled by a political party. This challenge can be directly aimed at the opponent, or it can be communicated to other audiences using a variety of media. In public means that this is more than a joke or humorous critical comment whispered in secret. One can observe someone doing something without hiding it, although the performers might try to hide their identity. The stunts are political in the broad sense, as they comment on a political theme of how society should be organised. As to their humorous dimension, many different definitions of what is humorous exist, but both within psychology and sociology what is known as "the incongruity tradition" prevails. This definition has emotional, social and cognitive aspects, and requires that the person who experiences something as humorous make a cognitive shift from a non-humorous to a humorous mode, and experience an incongruity (Mulkay 1988; Davis 1993; Palmer 1994; Martin 2007; Tsakona \& Popa 2011). Humorous political stunts seem to be a choice for those who communicate critique or alternatives to the prevailing order from a subordinate or marginal position, aiming to disrupt or transform the status quo via revealing and/or constructing incongruities. I have not identified any stunts in favour of the status quo, but this possibility is not excluded by the definition.

Speier (1998: 1353) writes that there are more jokes from "above" at the expense of the downtrodden than from below targeted upwards, but does not document this claim. Since his source of data mainly involves speeches and biographies of statesmen, it is highly unlikely that he should find evidence of upward directed humour there. The idea of humour's potential for reinforcing social hierarchies appears now and then (Palmer 1994; Martin 2007), with a reference to two studies in two psychiatric wards where the high ranked staff initiated joking more often than lower ranked staff during staff meetings (Coser 1960; Sayre 2001). However, the data for these studies are from formal meetings, not recordings of what happens when the high ranked staff is not present. Coser (1960) even specifically mentions that the findings might have been different in more informal settings. Other studies with organisational theory as their point of departure have documented humour when the employees are not observed by their superiors, and found that there can be much humour in the workplace at the expense of those on top of the hierarchies, including in places with very hard working conditions and systematic suppression of unions (Rodrigues \& Collinson 1995; Taylor \& Bain 2003; Lien Huong 2007). Tsakona \& Popa (2011) have also shown that political humour is more often than not about those in power. Scepticism, however, towards the rebellious potential of humour is not unusual. Billig (2005), for example, shows how humour also serves to enforce social order through ridicule and mockery. Some of the researchers who focus on political jokes (Benton 1988; Hong 2010) or medieval folly (Zijderveld 1982) also have the tendency to become sceptical. Such studies, together with the data presented here, show that humour has a potential for being both rebellious and reinforce social order. It is not possible to draw general conclusions about all humour from one type of source or one type of humour.

There exists a substantial amount of documentation of various forms of political humour in circumstances ranging from democracies to dictatorships and across time, some focusing on more private forms of humour such as whispered jokes, others on publicly performed humorous stunts (Obrdlik 1942; Pi-Sunyer 1977; Kanaana 1990; Stokker 1997, 2001; Davies 1998, 2007; 't Hart \& Bos 2007; Branagan 2007; Sørensen 2008; Hong 2010; Day 2011). Some of these studies say much about what happens in a particular case, but they 
have not looked at what they have in common with other cases, and how they differ. None has attempted to categorise grassroots political stunts according to their relations with power holders.

\section{Five types of grassroots political stunts}

As part of an ongoing study of how humour can affect relations of power, I have collected and analysed examples of humorous political stunts. The cases have been collected by searching academic literature on nonviolent direct action, snowball sampling, and from the mass media. The study also includes a participatory action research project that uses data collection methods such as participant observation and semi-structured interviews. So far, more than 40 examples mainly performed by grassroots political groups, but also some including professional comedians, have been identified. The majority of them are described in the Scandinavian and English languages in academic literature and the mass media. The purpose has been to start the exploration of this apparently growing type of political activism, expecting that, in the future, language and geographic diversity will disclose even greater variety. In this article I introduce a model for analysing humorous political stunts. The selection criteria for the cases presented here have been maximum diversity in time, place, political context and the way the stunt is carried out. The purpose is to highlight central aspects of humorous political stunts as well as the width of this phenomenon.

For each of the stunts, I started out by identifying what techniques they use in order to generate their humour, taking Berger's (1993) 45 techniques as the point of departure. Although his techniques were useful to describe what is funny in most of the examples, sometimes the framework did not fit very well. This may be due to the fact that Berger did not intend to investigate what happens in power relationships where humour is involved, but to identify general techniques that generate all humour.

Next I started to look at the ways activists attempt to undermine and transcend the rationality presented by the power holders. The pretence that this is not protest is a central element in almost all of them. The ways that this pretence is presented can be classified into 5 types, based on the different ways they attempt to undermine the rational communication of their opponent, and to transcend the established relations of power. I have called the different styles or approaches supportive, corrective, naive, absurd, and provocative. As with all categorisations, some cases fit the categories more clearly than others. Nevertheless, these 5 types transcend power relations in distinct ways independent of the techniques used to generate the fun. For example, exaggeration and irony are central in much political humour and can be found in several of the 5 types.

\subsection{Supportive}

Supportive humorous stunts are framed as attempts to help, support, protect from harm, and celebrate. Those who carry out supportive stunts appear supportive and rational, but what happens is that the target is invalidated. The pranksters do not openly dismiss the truth and rationality the power holders and representatives of the dominant discourses present; instead, their truth is exaggerated and overemphasised. Usually irony plays an important role in supportive humorous stunts, since the support is only pretended. The target will know that they are being watched, and the audiences are presented with an image of the power holders' vulnerable sides. Here the protesters do not appear irrational in their relation to what they actually oppose, as they are constructive, helpful and supportive. By acting in this way they attempt to undermine their opponents' claims to truth and power and to transcend the unequal 
relations of power. For an audience who is used to conventional, non-humorous political protest, at first glance supportive stunts look like real support. Only a closer look reveals an underlying message that exposes and disconfirms those who first appeared to be receiving support.

In Belgium a network working against landmines and cluster munitions in 2005 sent a landmine clearance team to the headquarter of AXA, a bank which had increased its investment in mines while other banks were reducing their investment in this industry. In the press release they wrote:

Today, 18th October, activists from the campaign "My Money. Clear Conscience?" symbolically demined the headquarters of AXA in Brussels. A landmine clearance team went in search of landmines, cluster munitions and other controversial weapons. This action is needed more than ever, as research from Netwerk Vlaanderen reveals that AXA invests heavily in two new US landmine producers

(Netwerk Vlaanderen 2005b).

This stunt was a constructive attempt to highlight AXA's investment in landmines. Instead of staging a traditional political protest, the landmine clearance team, dressed in reflexive orange vests, protective helmets, and equipped with instruments for mine detection looked out for the safety of the employees of AXA. This way, they engaged with their opponent by applying a different type of logic to what the conflict was about. The demining team of approximately 10 people used orange and white tape to close off the area and displayed signs saying "danger, mines" and "demining in progress". In a 3-minute video about the action which enabled the continuation of the performance across time and space, the employees in AXA show emotions such as bewilderment, surprise, amusement and worry (Netwerk Vlaanderen 2005a). It seems apparent that they do not know what to do with the deminers. Landmines and cluster munitions are a serious issue, and there should be no doubt that the organisation is serious in its critique of AXA's continued investment in this type of weapon. At the time of the action, the Ottawa Treaty, an international ban on anti-personnel landmines, had been in place for 8 years. Netwerk Vlaanderen had been campaigning for more ethical investments for 3 years, and while most banks had decreased their investment in weapons, AXA had not been willing to cooperate with the group (Netwerk Vlaanderen 2005b). To make this more public, the group decided to do the demining action.

In sum, although this was only pretence and the employees seemed more bewildered than scared, and viewers knew that the landmine clearance team would not find any landmines or cluster munitions at the AXA headquarters in Brussels, it is obvious that they approach the conflict with a logic which differs from conventional protest.

In order to understand the humour, Berger's (1993) list of 45 humorous techniques is useful. Techniques from his list mentioned here are in italics. As in many other humorous stunts, Netwerk Vlaanderen uses the technique of irony. They say that they are there to search for landmines, but it is obvious for everyone involved that the real purpose is to highlight AXA's investment in this type of weapon. They do this by impersonating a mine clearance team and use allusion to hint at AXA's investment in landmines. The action is also an attempt to unmask the true colours of the company. However, the techniques do not say anything about the power relation between AXA and Netwerk Vlaanderen, and how that relation is affected by the stunt. This type of stunt fit the "supportive" category because it is framed as being helpful and concerned about other people's safety. For the opponent, it is challenging to find an adequate response to a supportive stunt because they are not openly criticised, but instead they seemingly receive support and help. 


\subsection{Corrective}

Corrective humorous stunts aim to transcend the inequality in power by presenting an alternative version of "the truth". They hijack the identity or the message of their target in order to suggest a correction. This type of stunt unmasks the dominant discourse by disclosing an alternative version of persons, institutions or messages. Just like in the supportive stunt, this happens when the discourse and rationality of the target are exaggerated and overemphasised. The pranksters "sneak in" while the powerful are looking the other way or are busy somewhere else, in order to reveal what they consider a more "correct" version of who the target really is. This way, the pranksters communicate to the power holders that they are being watched, but the corrective is usually performed for the sake of the audience to whom the true colours of the target are revealed. Corrective humorous stunts frequently share the same goal with non-humorous protests: they want to inform the public about an alternative version of the truth.

The Yes Men with their concept of "identity correction" are by now a world famous example of this (Harold 2007; Bichlbaum \& Bonanno 2009; Day 2011). This US-based group has impersonated representatives of the World Trade Organisation (WTO) and a number of multinational companies. They made worldwide headlines in 2004 when one of them appeared on BBC as a representative of the company Dow Chemical on live TV broadcast directly to 300 million viewers. The fake spokesperson announced that Dow would finally take responsibility for the Bhopal catastrophe in India in 1984, where poisonous gas leaked out of a pesticide plant and killed 5,000 people. It would also compensate the 20,000 survivors with permanent health damage that had been waiting for compensation for the past 20 years (Bichlbaum \& Bonanno 2009; Day 2011).

Many other groups have used similar tactics of hijacking identities and messages. An alternative understanding of the purpose of a Swedish government agency will serve as an illustration. In 2010, the Swedish government formed a new agency called Forsvarsexportmyndigheten (Swedish Defence and Security Export Agency, FXM). The purpose of this agency was controversial, and has been the centre of a debate about free speech on the Internet. In May 2010, the oldest Swedish peace organisation, Svenska Fredsoch Skiljedomsforeningen (Swedish Peace and Arbitration Society, SPAS) started a webpage called forsvarsexportmyndigheten.se. The page was a parody of the official page, which used the domain fxm.se. At a glance, the pages looked very similar in design, but the content presented the work of the agency in very different terms. On fxm.se, the agency describes its activities this way:

On August 12010 the government established the Swedish Defence and Security Export Agency, FXM, with the purpose of streamlining and better prioritising government efforts for Swedish defence export. An operational defence industry in Sweden has defence and security benefits. With the help of cost sharing and cost recovery the supply of equipment for the Swedish armed forces can become more cost effective

(Forsvarsexportmyndigheten 2011).

SPAS explains the purpose of the agency this way:

The Swedish Defence and Security Export Agency, FXM, should encourage economic gain for shareholders in the Swedish arms industry. The Agency is a government lobby institution paid by the Swedish tax payers and aims to sell as much weaponry as possible. Commercial interests are the guiding star. The running of the agency is based on the praxis which Swedish arms export, or what we call defence export, is characterised by: concerns for democracy, human rights or the risk of war are completely irrelevant

(SPAS 2011). 
The agency's reaction to this humorous political stunt was not humorous at all. When first asked by the media what they thought about the parody webpage, the agency had no comments (Samimi 2010). A few months later, FXM said that they had not wanted this domain name anyway, since they wanted to become known under its abbreviation, FXM, and the full name was too long and complicated for non-Swedish speakers (Jacobsen 2011). However, FXM then proceeded to file a formal complaint with .SE, the trust which regulates the Swedish domain name .se. In July 2011, the .SE ruled that SPAS had started the page in "bad faith" (the literal translation from Swedish is in fact "evil faith"), and that the organisation had no legitimate right to the domain, which should be handed over to FXM. If SPAS wanted to continue satirising over FXM, it could do so without using this domain name (.SE 2011).

Also in this case, Berger's (1993) techniques are useful for analysing why many people find this funny. It is a parody of the official webpage, acting in the old tradition of satire in order to criticise those in power. To FXM, what they do is an exaggeration of some aspects of the agency's work, while SPAS will insist that what they present is the truth in a language that everyone can understand, something which could be understood as unmasking.

In sum, on the surface, the corrective stunt seems to be acting within the frame of logic and rationality. By using techniques such as exaggeration and parody, they bring the vulnerabilities of powerful institutions to the attention of a wider public. Sometimes the mistakes of the powerful contribute to the fun, but the mistakes of others are not central for the corrective stunt to work.

The supportive and corrective stunts share some similarities. On the surface, they appear logical. Behind the initial apparent logic, they base their challenge to power on the moment where the audience must ask itself whether this is meant to be taken literally, or whether someone is joking. Although this is an area that has not been studied yet, the people who carry out these stunts assume that something important happens in that moment of uncertainty. When a reader or viewer asks him/herself "Is this serious? Do they really mean this?", s/he may be more open to new information and new perspectives. When political arguments are presented rationally using traditional ways of disseminating information such as leaflets, posters and speeches, most people respond with a prior formed opinion. However, some pranksters assume that humour can provide a cognitive "detour" or a "psychological circuit breaker" creating a moment of openness. Whether such a moment can really lead to a change in a person's view and deepen their insight depends on a number of factors, but at least there appears to be a possibility for getting the audience to re-examine their assumptions. This idea is not new. Guy Debord (1970) and the French Situationists already in the late 1950's and the 1960's worked with the concept of detournement. This was one of their strategies for deconstructing ready-made cultural products made for consumption. Harold (2007: 7) defines this as "a detouring of pre-existing Spectacular messages and images in an effort to subvert and reclaim them". This involves an altering of original concepts into something different that can express a deeper message. More recently this idea has also been the background for the concept of culture jamming especially targeting commercial advertising (Lasn 1999; Harold 2007; Day 2011).

\subsection{Naive}

In naive humorous stunts activists pretend not to understand that what they do can be interpreted as a protest, thus they bring the unequal relations of power to everyone's attention in a way which is rather direct, but covered behind naiveté. While the supportive and corrective stunts exaggerate and overemphasise the rationality of the power holders in order to get their message across, those who carry out naive stunts pretend that they are not aware 
that they have challenged any power. If anything looks like a protest, that must be a coincidence. The story of the good soldier Švejk who challenged the authority of the army without ever framing his actions as protest is a classic literary example of a naive prankster (Hašek 1974). The purpose of the stunt is not to present a more correct version or to unmask, but to utter a dissenting message under the disguise of naiveté.

In Burma, any kind of open criticism of the military junta has been discouraged for decades and anyone doing it ran a great risk. But in spite of the persecutions and harassment of all dissidents, political humour was repeatedly thrown right in the face of the regime. In 2010, on the day that opposition leader Aung San Suu Kyi was to be released from her house arrest, and much was still uncertain, a magazine which follows international sports made a remarkable front page. The magazine, called First Eleven, had a headline which said "Sunderland freeze Chelsea" and "United stunned by Villa and Arsenal advances to grab their hope" accurately referring to well known British soccer teams. So how was a headline about a football win so remarkable? Some of the letters were changed into a different colour, to reveal a second version of the text: "SU free. Unite and advance to grab the hope". Above the headline was a photo which added to the subversive message: "a striker going for goal as the opposing team moves in to block him" (Radio Australia 2010).

For this action, the newspaper was suspended for two weeks, a relatively light punishment if the history of repression in Burma is taken into consideration. A comparable example comes from Denmark during Nazi occupation 1940-1945. A creative butcher made an advertisement for sausages across his two doors. But when one of the doors was closed, the other door revealed an anti-Nazi message (Hong 2010).

These types of stunts fit the naive category not because the activists would be called naive by their opponents -quite on the contrary- but because they frame what they do in such a way that on the surface they are not doing anything wrong at all. They pretend to avoid the logic of power and protest altogether, and instead they simply do something which is normal behaviour under the circumstances - announce a football result and advertise sausages respectively.

Naive stunts are most difficult to explain using Berger's (1993) techniques. Although pretence plays a role in all types of humorous stunts, it is crucial for understanding the apparently naive, hence the 45 techniques are not really applicable. Berger does describe techniques for coincidences, innocence, misunderstandings and ignorance, but the way he uses the terms varies considerably from what is happening in the examples above. For instance, Berger explains a kind of coincidence which is based on embarrassment (Berger 1993: 29), and in his description of ignorance we laugh at those who are ignorant. The situation changes when someone is pretending to be innocent or ignorant - instead of laughing at them, we laugh with them. Neither is it appropriate to talk about mistakes and misunderstandings as the techniques used, since the Nazis and Burmese authorities were not fooled but fully understood that this was only pretended innocence. Berger mentions pretence when he writes about taking on a different identity, like impersonation, but that differs from the mechanism of defining the whole situation as something else.

\subsection{Absurd}

In absurd humorous stunts, the activists frame themselves as innocent clowns who point towards society's absurdities. Their relation to the rationality of the dominant discourse is to defy it altogether. The absurd stunt shares some similarities with the naive stunt regarding the apparent naiveté of the activists, but whereas the participants in the naive stunt appear not to understand, the absurd pranksters refuse to acknowledge any kind of rationality. Their message is that the whole world is absurd, including the apparently powerful. All claims to 
power and truth are challenged with silliness, slapstick or total craziness. Everyone is assumed to be participants in the play they stage, but the previously prevailing rules and roles are altered. The absurd pranksters are unlikely to suggest that this has anything to do with protest: it is only the context and the audience's interpretations which can reveal any intent to criticise.

When trying to give rational responses, the opponent is confronted with even more silliness and absurdity, with the world turned upside down. The only thing predictable is that the performers will continue to be unpredictable. All attempts to deal with this as conventional political opposition will only contribute new components to their absurd plays.

During martial law in the early 1980's in Poland, graffiti in favour of the illegal trade union Solidarity was quickly painted over by the authorities. This left "blobs" on the walls, so that everyone knew that this was covered graffiti. Activists who identified with a new group called Orange Alternative started to work on these "blobs" by giving them arms and legs so that they became little elves. According to Kenney, who has written about the Orange Alternative and its place in the fall of the communist regimes in central Europe, elves made passers-by "consider the point of the struggle over wall space, and wonder why little elves were threatening to the communists" (Kenney 2002: 158).

Several years later, the elves came to life at an Orange Alternative happening on Children's day, 1 June 1987, one of the happenings which became what Kenney (2002: 160) calls a "catalyst" for the Orange Alternative. An invitation to the happening was distributed at schools and universities around the city of Wroclaw, and almost 1,000 young people showed up. There they got a red cap, and then they were elves. Since it was Children's day, the elves handed out candy to people, danced and sang children's songs. The leader of the Orange Alternative called himself Major Fyderych, but he could not be present himself this day, since he was arrested just before the happening began. Nevertheless, the happening went ahead and the guitar player Jakubczak, another central person in the Orange Alternative, played and sang with the crowd. When the police started to take some of the elves to the police cars they followed without protesting, kissing the police and throwing candy out through the windows. Then the crowd started to shout "Elves are real". Accounts of this surreal celebration of Children's day went around Poland in the underground press, providing new images of what protest could look like (Kenney 2002: 1-2,157-164).

Orange Alternative was a small group that mainly worked in the city of Wroclaw, but later spread to other cities in Poland. They initiated happenings which brought colour and carnival to the greyness that characterised both the communist regime and the opposition in Solidarity. Instead of staging a protest march or a fast as other protesters did, they arranged events which involved the audience. In addition to candy, they also handed out toilet paper and sanitary pads (scarce during communism) on other occasions. The concept of "socialist surrealism" and the mocking of the socialist realities guided the happenings, but Orange Alternative was a co-organiser of events, not the only organiser, since the police and passersby also had a say in what was to happen (Peczak \& Krajewska-Wieczorek 1991: 51). The happenings were never an open expression of dissent, since any independent organising, no matter the reason, was a threat to the communist desire for total control.

In 1987 and 1988, there was a happening on average once or twice a month (Misztal 1992), and another major event took place on 16 February 1988. This was carnival time, and Orange Alternative invited everyone to the surreal version of carnival in socialist Poland - the "ProletaRIO Carnival". This time the only dress code was carnival costume, and the crowd of 3,000-5,000 people included a skeleton, Ku Klux Klan men, smurfs, and Red Riding Hood together with a wolf. Official radio first reported the invitation, thinking it was an idea invented by the authorities. Finally, blue helmet police joined the crowd, but they were not there to party, but to arrest and take the carnival to the police station. In the official press this 
was presented as student foolishness that had to be stopped in order not to create traffic chaos in the afternoon rush-hour (Kenney 2002: 1-2,157-164).

In contrast to Solidarity, Orange Alternative was unpredictable and irrational. The regime never knew what would come next. The little elves did not resist arrest, but instead kissed the police and gave them flowers. This way, they became difficult for the regime to repress, since arresting someone for playing an elf seems ridiculous, even for communists. In the beginning, Orange Alternative was just as critical of Solidarity and the Church as of the communist regime (Misztal 1992: 61), and it was the regime itself which pushed the alternative more and more in the direction of protest. The happenings became a training ground for protest and socialised people to the idea of independent organising. They encouraged people to come out in the streets where they learned that a few hours of detention was not that dangerous after all (Kenney 2002: 190; Misztal 1992: 62). This way, Orange Alternative prepared people for what was to come a few years later, by lowering levels of fear.

The incongruity which Orange Alternative exposed was between everyday life under communist rule and the propaganda of the regime. Returning to Berger's (1993) techniques, Orange Alternative primarily relied on absurdity, evoking images from people's childhood which were transformed into the socialist surrealism of the Orange Alternative. Sometimes they also made parodies of communist slogans and ideology, for example, by meaningless references to "historical materialism" and exaggerated love for socialism (Kenney 2002: 160161).

A particular form of absurd stunts is carried out when clowns appear as part of a protest, such as the British group Clandestine Insurgent Rebel Clown Army, which has performed during, for example, G8 summits (Shepard et al. 2008; Routledge 2009; Bogad 2010) and inspired many other protesters in Europe and other parts of the world to perform in similar ways (Routledge 2012). The clowns also rely on absurdity as well as exaggeration, irony and slapstick.

The absurd stunt is not as confrontational as the provocative stunt which I will turn to below, but rather attempts to be an eye-opener. It is the type of stunt which is the furthest away from protest, since it might just as well expose hierarchies and domination within a protest movement. To the degree it is possible to talk about design at all with this type of stunt, it is intended to make people question everything they hear and see. The absurd stunt questions all dogmas and only vaguely hints towards possible political alternatives. In comparison, the corrective stunt brings forward an idea about what a more "correct" presentation of a person, company or message could be.

\subsection{Provocative}

Provocative humorous stunts are the type of stunts closest to conventional protest since they generate their humour simply by daring to directly confront those in power. The pranksters do not deny the unequal relations of power, as in absurd stunts, or present any alternatives like the corrective or constructive stunts do: they simply appear not to care about the consequences of their actions. That way the activists amuse and impress their audiences with their boldness and devil-may-care attitudes. The almighty who are confronted with a provocative stunt become ridiculous since they are humiliated right under their nose, and turn out not to have total control, after all. The pranksters openly act as provocateurs in order to expose vulnerabilities and humiliate the conceited power holders. The pranksters speak a message of lack of fear both to the targets and to other audiences.

In Russia, an art collective called Voina has made itself loved and infamous because of its creative stunts that expose Russian authorities. In June 2010, they painted a giant penis on 
Liteiny Bridge in St. Petersburg in just 23 seconds. Liteiny Bridge is a bascule bridge, and the action was done just before it was opened to let a ship pass. When that happened, the penis was standing erect for several hours just in front of the unpopular secret police (FSB) headquarters in St. Petersburg (Sturdee 2011).

Russian authorities were presumably not very happy about this painting, and had it removed straight away. Members of Voina are facing prison sentences for this and similar actions (Sturdee 2011). The circumstances in authoritarian Russia make this different from performing the same stunt in a more democratic country.

In terms of Berger's (1993) techniques, one might say that they use the grotesque and it is of course a severe insult to the FSB. It is also a way of ridiculing. The incongruity lies between a big powerful state and the "little people", and it can hardly be interpreted as anything else than defying. Like the innocent stunts, it is difficult to understand the provocative stunts outside of the power relations they are part of.

Although the supportive, corrective, innocent, and absurd stunts are confrontational as well, the provocative appear to depend especially on the audiences' recognition of the irreverent attitude of the activists. From sympathetic bystanders they get a "wow, how courageous". However, many other nonviolent actions can generate that feeling without being humorous at all. For instance, the Freedom Flotillas that in 2010 and 2011 attempted to break the Israeli blockade of Gaza were also considered bold actions. In 2010, 9 activists were killed during this attempt to bring humanitarian aid to Gaza. The convoy was attacked by Israeli soldiers while it was still in international waters. As another example, the ploughshares movement does nonviolent disarmament actions of weapons in both Europe and the US. Using hammers as a symbolic reference to the Bible verse about turning swords into ploughshares, they enter arms factories and military areas in order to start the disarmament themselves. Afterwards they await the police. Especially in the US, these actions have resulted in long prison terms, causing some people within the peace movement to consider these acts bold and courageous. They are also provocative, but not humorous at all. What makes them different are their attitude towards those they challenge, and their expectations of reactions. The Freedom Flotilla movement and the ploughshare activists care a great deal about the reactions of states and companies and thereby indirectly recognise their power and the rationality they represent. Although such actions use much symbolism, they are more than 'just' a performance.

In contrast, the participants in a humorous provocative stunt appear unconcerned about the power of the institutions they attack: the Voina type of action does not present itself as if it has any other purpose than to provoke and send a different message to a large audience: "We do not care very much about potential consequences". Nevertheless, only the activists themselves know if they expect their actions to have consequences that are more than symbolic. Voina's action suggests "You are not that powerful after all, because we can do this right under your nose, and we refuse to be scared of you". And to the wider audience it adds "Why are you so scared?" "See, they just pretend to be powerful! Why do you believe that?" With this refusal to be intimidated they contribute to transcending the rationality of the socalled powerful. When someone finally says that the emperor has no clothes, people's fear may start to decrease, and what started out symbolically might set the snowball rolling towards more sustained challenges.

Other cases fitting in this category are some of the actions carried out by the group Otpor, which played an important role in bringing down the Serbian president Slobodan Milosevic in 2000. One of their actions called "Dinar za Smenu" ("Dinar for change"; dinar is the Serbian currency). Otpor activists invited the general public to bang on a barrel with the photo of Milosevic, something which was also a clear provocation. However, the action was also an amusing mocking of one of Milosevic's campaigns to support agriculture and a 
wordplay with "Smenu". In addition to "change" it also means "purge" and "resignation". When the police confiscated the barrel, Otpor could claim that it had collected enough money for Milosevic's retirement, and that the police would bring it to him (Sørensen 2008).

The provocative stunt does not attempt to appear as a serious threat to those in power. This can either be because the organisers really do not have any intentions of doing more than a harmless prank, or it might be because they find a humorous strategy more likely to be successful. This is exactly why power holders are caught in such a dilemma about how to react. From a rational point of view what authoritarian state leader would be scared because someone paints a giant penis or shows contempt by hitting a photo of them? After all, they have armed police and military troops ready to back them up. That they bother to react can be interpreted as a sign that these types of humorous stunts are indeed unsettling.

Just as the supportive and the corrective stunts share some similarities, so do the absurd and the provocative ones. Even if the absurd stunt seems to be the furthest away from conventional protest, and the provocative stunt the closest, both the absurd and the provocative stunt refuse rationality. The devil-may-care attitude of the provocative stunt is admired by some because it is seen as courageous and bold. It is a clear provocation and not camouflaged as anything else. The absurd stunt refuses the existence of all rationality. It might be interpreted as a disguise for protest, but only the pranksters themselves will know if they consider the world absurd altogether, or if they see absurdity as a useful tool for communicating dissent.

The problematic situation for a state leader or others in power positions is that if they let a few challenge them, more may follow. And that could end up in a situation out of control. At the same time they are also aware that brutal force against humorous actions may backfire and a reaction against repression may also spin out of control.

\section{Conclusion}

One or more of the techniques described by Berger (1993) are found in most of the aforementioned cases and help us identify the humorous mechanisms exploited in humorous political stunts. Furthermore, emphasis here was given to the dynamics of the power relations between the pranksters and those they challenge. Dividing humorous political stunts into different types makes it easier to analyse exactly how the pranksters challenge the truths and rationalities that dominant discourses and their representatives aim to uphold. The model with 5 different types presented here incorporates a huge variety of approaches to challenging power.

The supportive stunt was exemplified by the Belgium land mine clearance team which went into the AXA headquarters in order to demine the building. Their apparent concern for the safety of the workers was a disguised protest intended to invalidate AXA's investment practices and expose the bank to the general public. A supportive stunt does not dismiss the rationality of those it exposes, but exaggerates and overemphasises it through irony.

Swedish SPAS and their parody webpage of the government agency which was established to bolster Swedish arms export, are an example of a corrective stunt which also at first glance appears to work within a rational framework. The corrective is a way of signalling that the so-called powerful are being watched, but it is just as much directed towards a different audience who are presented with an alternative message concerning who the target of the stunt really is and what are the true colours of its message. The information presented in a corrective stunt is rational in the sense that it is just as possible and true as the original message, but the hijacking of the target's identity together with the exaggerations and irony undermine the target's claim to the one-and-only truth. 
Already the French Situationists and their concept of détournement assumed that a mental detour would make the audience more open to alternatives. The analysis of the examples of supportive and corrective stunts reveals how these two types of stunts thrive on the moment when their audiences question whether this is really true or whether someone is pulling a trick. However, much research remains to be done on what happens during this "opening" to alternatives, in order to determine if such humorous political stunts are actually able to help the audience reach a different state of mind or a deeper level of understanding than conventional types of protest.

The naive stunt has a different way of refusing the rationality of those in power; those who carry it out appear not to be aware that they have posed a challenge. If anything looks like a protest, that must be a coincidence. Nevertheless, since there is logic to what they do they leave themselves vulnerable to persecution, as in the example from the Burmese sports magazine. It is not the mistakes of the authorities which cause laughter, but the boldness to challenge and hide behind a facade of innocence.

The absurd stunts refuse rationality altogether, and in this tradition the activists will respond to all reactions from those in power with further absurdity, as did the Orange Alternative in Poland. Since the absurd is bound to remain within the absurd, it cannot suggest alternatives and improvements without leaving its position. If the participants in an absurd stunt suddenly should decide to suggest solutions to a problem in a rational way, they leave themselves vulnerable to critique that they are (mis)using the concept of absurdity.

The provocative stunt also refuses rationality, but what its participants refuse is to let themselves be intimidated. As described in the example from Voina in Russia, the provocative stunt displays a devil-may-care attitude which causes amusement when the almighty, such as the Russian secret police, is proven incapable of preventing such an attack right under their nose. Even those supposed to exert total control can be brought down from their pedestals. This boldness is something the provocative stunt has in common with the naive, but they differ in how they display their courage. Whereas the provocative stunt seems not to care, the naive appear not to understand.

Frequently humorous political stunts place the people in power in a dilemma about how to react. Within studies of nonviolence, this is called a "dilemma action" (Lakey 1987; Sørensen \& Martin to appear). It leaves power holders with few options about how to react, and no matter what they do, the pranksters will benefit from it. In the case of forsvarsexportmyndigheten.se, the authorities could have let SPAS continue to use the domain, and the organisation would have continued to distribute its satiric messages. When they reacted, their complaint to .SE created additional unwanted attention. None of the possibilities were ideal for FXM. In all examples above, except for the landmines clearing, the dilemma triggered a negative reaction from those it was directed against. Frequently, however, humorous political stunts are ignored in the hope of minimising attention to what they are criticising.

Humorous stunts are a game of pretence, interpretation and appearance. They operate within a play frame, and depend on establishing a resonance with one or more audiences that this is humorous, and that ambiguity and multiple meanings and interpretations are acceptable (Mulkay 1988; Davis 1993). For all these examples, the opponents of the pranksters may not find them funny at all. However, as Palmer has pointed out (Palmer 1994), it is not the privilege of the butt of a joke to decide whether something is funny or not. The play frame and the use of humour do not mean that the stunt is devoid of a serious message; in some cases this message is even deadly serious for the people involved. Some of the stunts are realised under regimes with a long record of severe repression, such as the Burmese military junta and Nazi occupiers. Challenges to their version of the truth are not treated mildly, even 
when the challenge is done with humour. Humorous stunts are just one method in a greater struggle for power and meaning-making, which is not playful at all.

Much research on political humour remains to be done before we can understand if and how humour influences relations of power, especially regarding the effect the humour actually has to its recipients. Although I have shown how humorous political stunts are much more than a vent for frustration, it remains to be investigated if some types of stunts are more useful towards certain categories of opponents, or if some types of stunts are better in the beginning of a campaign in order to raise awareness, while others are more useful later on for presenting alternatives. In order to illustrate such dynamics, more data is needed. However, it should be underlined here that pointing to the potential that humorous political stunts can undermine power is not the same as saying that all political humour is subversive.

This model of 5 types of stunts was developed to better understand grassroots political groups' challenges to those considered powerful. Whether a similar categorisation could be applied to other types of political humour, such as cartoons, stand-up comedy or jokes, also remains to be studied.

\section{Acknowledgments}

The author would like to thank the Faculty of Arts, University of Wollongong, for a grant that supported this research. Jorgen Johansen, Jason MacLeod, Brian Martin, Stellan Vinthagen and the two anonymous reviewers from the European Journal of Humour Research provided valuable comments and suggestions at different stages during the work on this article. Thanks are also due to the organisers and participants in the political humour panel at the 24th ISHS Conference in Krakow, June 2012 for positive feedback and encouragement.

\section{References}

.SE (2011). 'Beslut 487' [Decision 487], 4 July. http://www.iis.se/docs/beslut_forsvarsexportmyndigheten.se_pdf (accessed 5 April 2012).

Benton, G. (1988). 'The origins of the political joke,' in C. Powell \& G. E. C. Paton (eds.), Humour in Society: Resistance and Control. New York: St. Martin's Press, pp. 33-55.

Berger, A. A. (1993). An Anatomy of Humour. New Brunswick: Transaction Publishers.

Bichlbaum, A. \& Bonanno, M. (2009). The Yes Men Fix the World. Docudramafilms.

Billig, M. (2005). Laughter and Ridicule: Towards a Social Critique of Laughter. London: Sage.

Bogad, L. M. (2010). 'Carnivals against capital: Radical clowning and the global justice movement.' Social Identities, 16 (4), pp. 537-557.

Branagan, M. (2007). 'The last laugh: Humour in community activism.' Community Development Journal, 42 (4), pp. 470-481.

Coser, R. L. (1960). 'Laughter among colleagues.' Psychiatry: Journal of the Biology and the Pathology of Interpersonal Relations, 23 (1), pp. 81-95.

Davies, C. (1998). Jokes and Their Relation to Society. Berlin \& New York: Mouton de Gruyter.

Davies, C. (2007). 'Humour and protest: Jokes under Communism.' International Review of Social History, 52 (Supplement S15), pp. 291-305.

Davis, M. S. (1993). What's So Funny? The Comic Conception of Culture and Society. Chicago: The University of Chicago Press.

Day, A. (2011). Satire and Dissent: Interventions in Contemporary Political Debate. Bloomington: Indiana University Press.

Debord, G. (1970). Society of the spectacle. Detroit: Black \& Red.

Forsvarsexportmyndigheten (2011). Om FXM [About FXM], 5 September. http://fxm.se/om-fxm (accessed 5 September 2011).

Harold, C. (2007). OurSpace: Resisting the Corporate Control of Culture. Minneapolis: The University of Minnesota Press. 
Hašek, J. (1974). The Good Soldier Švejk and His Fortunes in the World War. New York: Crowell.

Hong, N. (2010). 'Mow 'em all down grandma: The "weapon" of humour in two Danish World War II occupation scrapbooks.' Humour: International Journal of Humor Research, 23(1), pp. 27-64.

Jacobsen, O. (2011). 'De skal fa Sverige att exportera mer vapen' [They are to help make Sweden export more weapons]. Metro, 26 January. http://www.metro.se/metro-teknik/de-ska-fa-sverigeatt-exportera-mer-vapen/Objkaz!30645 (accessed 29 August 2011).

Kanaana, S. (1990). 'Humour of the Palestinian "Intifada"'. Journal of Folklore Research, 27 (3), pp. 231-240.

Kenney, P. (2002). A Carnival of Revolution - Central Europe 1989. Princeton: Princeton University Press.

Lakey, G. (1987). Powerful Peacemaking: A Strategy for a Living Revolution. Philadelphia: New Society Publishers.

Lasn, K. (1999). Culture Jam: The Uncooling of America, 1st edition. New York: Eagle Brook.

Lien Huong, N. (2007). 'Jokes in a garment workshop in Hanoi: How does humour foster the perception of community in social movements?' International Review of Social History, 52 (Supplement S15), pp. 209-223.

Martin, R. A. (2007). The Psychology of Humour: An Integrative Approach. Burlington: Elsevier.

Meyer, J. C. (2000). Humour as a double-edged sword: Four functions of humour in communication. Communication Theory, 10 (3), pp. 310-331.

Misztal, B. (1992). 'Between the state and solidarity: One movement, two interpretations - The Orange Alternative movement in Poland.' The British Journal of Sociology, 43 (1), pp. 55-78.

Mulkay, M. J. (1988). On Humour: Its Nature and Its Place in Modern Society. Cambridge: Polity Press.

Netwerk Vlaanderen (2005a). Demining action 18/10/2005. http://www.antimilitaristas.org/IMG/mpg/Netwerk_AxA.mpg (accessed 1 June 2013).

Netwerk Vlaanderen (2005b). Demining team begins its work at AXA, 18 October. http://www.netwerkvlaanderen.be/en/index.php?option=com_content\&task=view\&id=47\&Item id=268 (accessed 12 October 2011).

Obrdlik, A. J. (1942). “'Gallows humour” - A sociological phenomenon.' The American Journal of Sociology, 47 (5), pp. 709-716.

Palmer, J. (1994). Taking Humour Seriously. London: Routledge.

Peczak, M., \& Krajewska-Wieczorek, A. (1991). 'The Orange Ones, the street, and the background.' Performing Arts Journal, 13 (2), pp. 50-55.

Pi-Sunyer, O. (1977). 'Political humour in a dictatorial state: The case of Spain.' Ethnohistory, 24 (2), pp. 179-190.

Radio Australia (2010). 'Burma and the difficult art of humour,' November 22. http://blogs.radioaustralia.net.au/today/burma-and-the-art-of-humour (accessed 29 March 2011).

Rodrigues, S. B., \& Collinson, D. L. (1995). "Having fun"? : Humour as resistance in Brazil.' Organisation Studies, 16 (5), 739-768.

Routledge, P. (2009). 'Toward a relational ethics of struggle: Embodiment, affinity, and affect,' in R. Amster, A. DeLeon, L. A. Fernandez, A. J. Nocella \& D. Shannon (eds.), Contemporary Anarchist Studies: An Introductory Anthology of Anarchy in the Academy. New York: Routledge, 82-92.

Routledge, P. (2012). 'Sensuous solidarities: Emotion, politics and performance in the Clandestine Insurgent Rebel Clown Army.' Antipode, 44 (2), pp. 428-452.

Samimi, A. (2010). 'Svenska Freds kapar krigsmyndighetens doman' [SPAS hijack war agency's domain]. Dagensmedia.se, $26 \quad$ November. http://www.dagensmedia.se/nyheter/kampanjer/article3023811.ece (accessed 29 August 2011).

Sayre, J. (2001). 'The use of aberrant medical humour by psychiatric unit staff.' Issues in Mental Health Nursing, 22 (7), pp. 669-689.

Shepard, B., Bogad, L. M. \& Duncombe, S. (2008). Performing vs. the insurmountable: Theatrics, activism, and social movements. Liminalities: A Journal of Performance Studies, 4 (3), pp. 130.

SPAS (2011). www.forsvarsexportmyndigheten.se (accessed 25 August 2011). 
Speier, H. (1998). 'Wit and politics: An essay on power and laughter.' American Journal of Sociology, 103 (5), pp. 1352-1401.

Stokker, K. (1997). Folklore Fights the Nazis: Humour in Occupied Norway, 1940-1945. Madison: The University of Wisconsin Press.

Stokker, K. (2001). 'Quisling humour in Hitler's Norway: Its wartime function and postwar legacy.' Humour: International Journal of Humour Research, 14 (4), pp. 339-357.

Sturdee, N. (2011). 'Don't raise the bridge: Voina, Russia's art terrorists.' The Guardian, 12 April. http://www.guardian.co.uk/artanddesign/2011/apr/12/voina-art-terrorism?INTCMP=SRCH (accessed 17 December 2011).

Sørensen, M. J. (2008). 'Humour as a serious strategy of nonviolent resistance to oppression.' Peace \& Change, 33 (2), pp. 167-190.

Sørensen, M. J. \& Martin, B. (to appear). 'Dilemma actions: Analysis of an activist technique.' Peace \& Change.

't Hart, M. C. \& Bos, D. (eds.) (2007). Humour and Social Protest. Cambridge: Press Syndicate of the University of Cambridge.

Taylor, P. \& Bain, P. (2003). 'Subterranean worksick blues': Humour as subversion in two call centres.' Organisation Studies, 24 (9), pp. 1487-1509.

Tsakona, V. \& Popa, D. E. (eds.) (2011). Studies in Political Humour: In between Political Critique and Public Entertainment. Amsterdam \& Philadelphia: John Benjamins.

Zijderveld, A. C. (1982). Reality in a Looking-Glass: Rationality through an Analysis of Traditional Folly. London: Routledge \& Kegan Paul. 